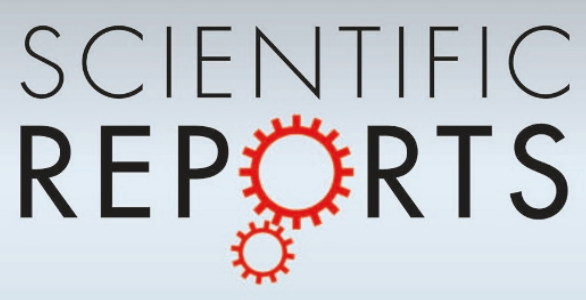

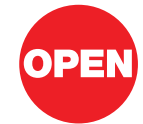

SUBJECT AREAS:

ELECTROCHEMISTRY

MATERIALS CHEMISTRY

ELECTRONIC MATERIALS AND

DEVICES

ENERGY

Received

18 January 2012

Accepted

26 July 2012

Published

9 August 2012

Correspondence and requests for materials should be addressed to Y.L. (ynliu@mail.xjtu. edu.cn)

\section{A direct borohydride fuel cell with a polymer fiber membrane and non-noble metal catalysts}

\author{
Xiaodong Yang, Yongning Liu, Sai Li, Xiaozhu Wei, Li Wang \& Yuanzhen Chen \\ State Key Laboratory for Mechanical Behavior of Materials, Xi'an Jiaotong University, Xi'an 710049, PR China.
}

Polymer electrolyte membranes (PEM) and Pt-based catalysts are two crucial components which determine the properties and price of fuel cells. Even though, PEM faces problem of fuel crossover in liquid fuel cells such as direct methanol fuel cell (DMFC) and direct borohydride fuel cell (DBFC), which lowers power output greatly. Here, we report a DBFC in which a polymer fiber membrane (PFM) was used, and metal oxides, such as $\mathrm{LaNiO}_{3}$ and $\mathrm{MnO}_{2}$, were used as cathode catalysts, meanwhile CoO was used as anode catalyst. Peak power density of $663 \mathrm{~mW} \cdot \mathrm{cm}^{-2}$ has been achieved at $65^{\circ} \mathrm{C}$, which increases by a factor of 1.7-3.7 compared with classic DBFCs. This fuel cell structure can also be extended to other liquid fuel cells, such as DMFC.

uel cells are promising power-generation technology for automotive applications, which convert chemical energy directly into electricity while causing little pollution. A direct borohydride fuel cell (DBFC) is a kind of liquid fuel cell, which has advantages of high open circuit voltage (1.64 V), high fuel energy density (9.3 Wh $\cdot \mathrm{g}^{-1}$ for $\mathrm{NaBH}_{4}$ and $6.5 \mathrm{Wh} \cdot \mathrm{g}^{-1}$ for $\mathrm{KBH}_{4}$ ), and fast borohydride oxidation reaction (BOR) kinetic ${ }^{1}$. In $\mathrm{DBFC}$, the cell reaction principle is as follows:

$$
\begin{gathered}
\text { Anode : } \mathrm{BH}_{4}^{-}+8 \mathrm{OH}^{-} \rightarrow \mathrm{BO}_{2}^{-}+6 \mathrm{H}_{2} \mathrm{O}+8 e^{-} \\
E_{\text {anode }}^{o}=-1.24 \mathrm{~V}(\text { vs. SHE }) \\
\text { Cathode }: 2 \mathrm{O}_{2}+4 \mathrm{H}_{2} \mathrm{O}+8 e^{-} \rightarrow 8 \mathrm{OH}^{-} \\
E_{\text {cathode }}^{o}=0.40 \mathrm{~V}(\text { vs. SHE }) \\
\text { Overall : } \mathrm{BH}_{4}^{-}+2 \mathrm{O}_{2} \rightarrow \mathrm{BO}_{2}^{-}+2 \mathrm{H}_{2} \mathrm{O} \\
E_{\text {cell }}^{o}=1.64 \mathrm{~V}
\end{gathered}
$$

Nafion membrane, polymer electrolyte membrane (PEM), is indispensable in fuel cells ${ }^{2,3}$, which provides electric insulator between anode and cathode and prevents reactant crossover from the anode to the cathode. However, crossover is still a serious problem due to the diffusion and osmotic drag that lower the power output by maximum up to $50 \%$ in liquid fuel cells ${ }^{4}$. Much research has been conducted on the details of the transport of protons or ions through the polymer matrix and on novel methods of improving its properties, but the crossover has not yet been solved as well as the cost of the PEM ${ }^{4,5}$.

The cost of noble metal catalyst is another factor limiting fuel cells commercialisation. According to United States Department of Energy's (DOE's) forecasts in 2007, platinum-based catalysts alone would account for 38$56 \%$ of the cost in a PEM fuel cell stack ${ }^{6}$. The cathode consumes around $90 \%$ of platinum catalyst used in both anode and cathode due to its sluggish oxygen reduction reaction (ORR) kinetics ${ }^{7}$. Therefore, non-Pt-based catalysts have been greatly studied. Recently, great progress has been achieved in this field. It was found that $\mathrm{Co}-\mathrm{N}-\mathrm{C}$ and Fe-N-C type complexes, which were made by pyrolyzing transition metal precursors with nitrogencontaining precursors supporting on conductive polymer ${ }^{8}$ or highly microporous carbon ${ }^{9}$ or metal-organicframework $^{10}$, have catalytic activity for the ORR comparable with state-of-the-art Pt-based catalyst. Although 
the performance and stability of Pt-based catalysts have been greatly improved in $\mathrm{H}_{2} / \mathrm{O}_{2}$ PEM fuel cells ${ }^{11-13}$, its efficiency in DBFCs is still in a low level. The peak power densities ranged at $20-200 \mathrm{~mW} \cdot \mathrm{cm}^{-2}$ when Pt or Pt-based catalysts are used ${ }^{2,3}$, while they were in ca. 1,000 $\mathrm{mW} \cdot \mathrm{cm}^{-2}$ when in $\mathrm{H}_{2} / \mathrm{O}_{2}$ PEM fuel cells. Crossover is the main reason for this phenomenon. Pt-based catalysts promote ORR and BOR simultaneously when liquid fuel permeates through PEM and arrives in cathodes ${ }^{14}$, thus cathode efficiency is greatly reduced. It was found that some non-noble metal catalysts for ORR have excellent tolerance with respect to borohydride, including $\mathrm{EuO}_{2}{ }^{15}, \mathrm{MnO}_{2}{ }^{16}$, $\mathrm{La}_{2} \mathrm{O}_{3}{ }^{17}, \mathrm{CeO}_{2}{ }^{18}, \mathrm{Fe} / \mathrm{CoPc}{ }^{19,20}$ and perovskite-type oxides $\left(\mathrm{LaNiO}_{3}\right.$, $\left.\mathrm{LaCoO}_{3}\right)^{21,22}$. However, their peak power densities were lower than $120 \mathrm{~mW} \cdot \mathrm{cm}^{-2}$ at ambient temperatures, which are much lower than that of PEMFCs. Therefore, improving the output of DBFCs is one of the most important targets as well as reducing costs.

\section{Results}

In this paper, we fabricated a DBFC with polymer fiber membrane (PFM) as a separator replacing of polymer electrolyte membrane (PEM). Figure la shows the structure of the DBFC with the PFM (DBFC-PFM). In the anode (2 in figure 1a), CoO was chosen as catalyst, which also had been used in our previous work $^{23}$. It is a merit of DBFCs that anodic catalysts can also be some non-noble metals such as hydrogen storage alloys and some other metallic compounds ${ }^{24-26}$.

The fiber materials in the PFM ( 3 in figure 1a) can be polypropylene or polyamide or polyvinyl alcohol. The photograph and scanning electron microscopy (SEM) image of the PFM are shown in figure $1 \mathrm{~b}$ and figure $1 \mathrm{c}$, respectively. The PFM is a permeable membrane and it just keeps the cathode and anode non-contacted to prevent short-circuits. The fibers in the membrane are neutral and there are no polarity groups grafted on the main chains in fiber. The pores and gaps between fibers allow liquid fuel and ions transporting or moving through the PFM freely. It has a good wetting nature and is easy to be saturated by liquid solution. So the PFM in DBFCs acts as a very thin liquid electrolyte layer and allows the anions and cations, including $\mathrm{BH}_{4}^{-}, \mathrm{OH}^{-}$and $\mathrm{Na}^{+} / \mathrm{K}^{+}$, to cross freely. In this situation, it is necessary for cathodic catalysts to have excellent tolerance to the poison of $\mathrm{BH}_{4}{ }^{-}$and good stability in alkaline solution. The cathodic catalysts $\left(\mathrm{LaNiO}_{3}, \mathrm{MnO}_{2}, \mathrm{La}_{2} \mathrm{O}_{3}\right.$ and $\left.\mathrm{CeO}_{2}\right)$ used in this study have been proved stable enough in alkaline solution and do not react with $\mathrm{BH}_{4}{ }^{-16-18,22}$.

In addition, a gas diffusion layer (5 in figure 1a) which was made by acetylene black and polytetrafluoroethylene (PTFE) was pressed with the cathodic active layer, which can efficiently prevent cathodeover-flood and have enough three phase area for ORR.

Figure 2a shows the performance of the DBFC-PFM. Classic DBFCs were fabricated with a PEM (Nafion NRE-211 or N-117) for a comparison. As shown in figure $2 \mathrm{a}$, the highest peak power densities can be obtained when using PFM as a membrane. The peak power density of the DBFC-PFM with $\mathrm{LaNiO}_{3}$ as cathodic catalyst reached $368 \mathrm{~mW} \cdot \mathrm{cm}^{-2}$ at $25^{\circ} \mathrm{C}$ and it increased by a factor of ca. 1.5 and 3.1 compared with the DBFCs using NRE-211 and N-117, respectively. Similarly, the peak power density of the DBFC-PFM with $\mathrm{MnO}_{2}$ as cathodic catalyst reached $216 \mathrm{~mW} \cdot \mathrm{cm}^{-2}$ and it increased by a factor of ca. 1.5 and 2.1, respectively. Moreover, the other $\mathrm{BH}_{4}{ }^{-}$-tolerant cathodic catalysts $\left(\mathrm{La}_{2} \mathrm{O}_{3}, \mathrm{CeO}_{2}\right)$ were also used in the DBFCs-PFM. And the performance increased by a factor of ca. 1.4-2.4 (Supplementary Figure 2S) compared to that of the DBFCs with Nafion membrane.

As the application temperature of DBFCs is in the range of 60$80^{\circ} \mathrm{C}$, we measured the performance of the DBFCs at $65^{\circ} \mathrm{C}$ with $\mathrm{LaNiO}_{3}$ (figure 2b), which has the best performance among the cathodic catalysts mentioned above. The peak power density of the DBFC-PFM is $663 \mathrm{~mW} \cdot \mathrm{cm}^{-2}$, which is increased by a factor of ca. 1.7 and 3.7 compared with that of the DBFCs employing NRE-211 and $\mathrm{N}-117$. At $0.6 \mathrm{~V}$, which is a meaningful voltage as suggested ${ }^{10}$, the power density of the DBFC-PFM with $\mathrm{LaNiO}_{3}$ is $640 \mathrm{~mW} \cdot \mathrm{cm}^{-2}$ at $65^{\circ} \mathrm{C}$. It is highly improved compared with the highest power density as reported ${ }^{27}$, the power density of $370 \mathrm{~mW} \cdot \mathrm{cm}^{-2}$ for DBFCs with $\mathrm{Co}(\mathrm{OH})_{2}$-PPY-C was obtained at $0.6 \mathrm{~V}$ at $60^{\circ} \mathrm{C}$. And it increases to a level comparable with the power density of $\mathrm{H}_{2} / \mathrm{O}_{2}$ PEMFC with the most promising non-noble metal catalyst $\left(750 \mathrm{~mW} \cdot \mathrm{cm}^{-2}\right.$ at $0.6 \mathrm{~V}$, $\left.80^{\circ} \mathrm{C}\right)^{10}$.

\section{Discussion}

To explain the different performances of DBFCs with different membranes, electrochemical impedance spectroscopy was measured and the results are shown in figure $2 \mathrm{c}$. Ohm resistance, which is represented by the intercept on real-axis ${ }^{28}$, is lower when PFM is used. And

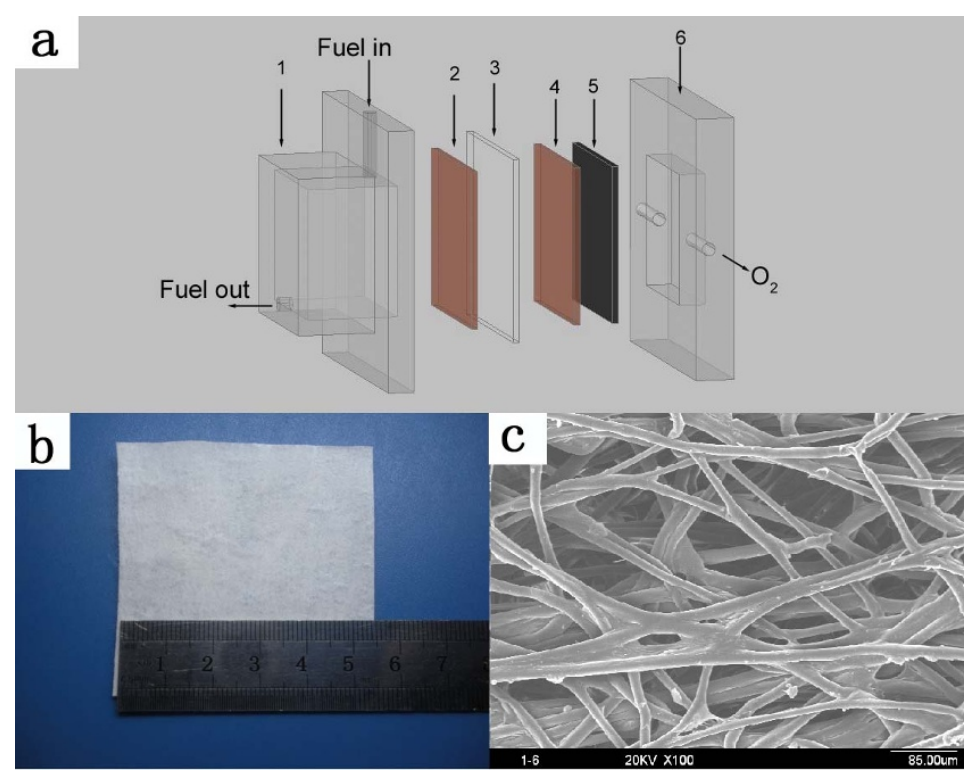

Figure 1 The structure of DBFC with PFM. (a) schematic structure of DBFC with PFM, 1 end plate with fuel container; 2 anode; 3 polymer fiber membrane (PFM); 4 cathodic active layer; 5 gas diffusion layer; 6 end plate with oxygen flow field. The photograph (b) and SEM image (c) of the PFM are shown. 

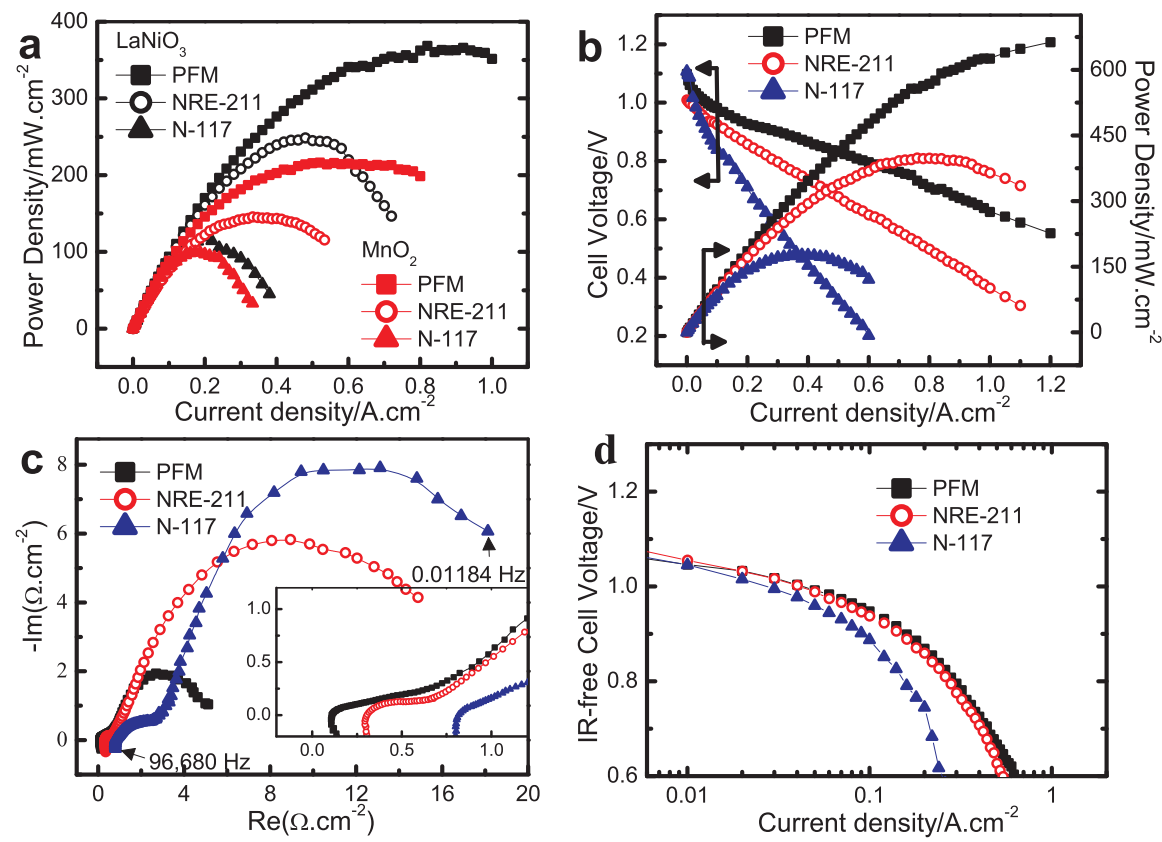

Figure $2 \mid$ Comparisons of the membranes. (a) Performances of the DBFCs with polymer fiber membrane (PFM) $(\boldsymbol{\square}, \mathbf{\square}), \mathrm{NRE}-211(\bigcirc, \bigcirc)$ and N-117 membranes $(\boldsymbol{\Delta}, \boldsymbol{\Delta})$, respectively. $\mathrm{LaNiO}_{3}(\boldsymbol{\square}, \bigcirc, \boldsymbol{\Delta})$ or $\mathrm{MnO}_{2}(\boldsymbol{\square}, \bigcirc, \boldsymbol{\Delta})$ was used as cathodic catalysts, respectively. The tests were performed at $25^{\circ} \mathrm{C}$. (b) Polarisation curves and performances of the DBFCs with PFM $(\boldsymbol{\square})$, NRE-211 ( $\bigcirc)$ and N-117 membranes $(\boldsymbol{\Delta})$, respectively, when $\mathrm{LaNiO}_{3}$ and CoO were used as cathodic and anodic catalysts, respectively, at $65^{\circ} \mathrm{C}$. (c) Electrochemical impedance spectrum of the cells using PFM ( $)$ ), NRE-211 ( $\left.\bigcirc\right)$ and $\mathrm{N}-117$ membranes $(\boldsymbol{\Delta})$ as separators, respectively. The high frequency part intercept on real-axis shows in the insert figure. $\mathrm{LaNiO}_{3}$ and $\mathrm{CoO}$ were used as cathodic and anodic catalysts, respectively. The tests were performed at $25^{\circ} \mathrm{C}$. (d) IR-free polarisation curves obtained from the DBFCs are shown when PFM ( $\mathbf{\square})$, NRE-211 $(\bigcirc)$ and N-117 $(\boldsymbol{\Delta})$ is used, respectively. $\mathrm{LaNiO}_{3}$ and $\mathrm{CoO}$ was used as cathodic and anodic catalysts, respectively. The tests were performed at $25^{\circ} \mathrm{C}$.

it is $0.08663,0.2738$ and $0.7432 \Omega \cdot \mathrm{cm}^{-2}$ for PFM, NRE-211 and $\mathrm{N}$ 117 , respectively. The reaction resistance of the DBFCs-PFM presented by the arc at low frequencies ${ }^{29}$, including charge transfer and mass transport resistances, is lower than that of the DBFCs with NRE-211 and N-117. The DBFCs-PFM having lower ohm and reaction resistance can be explained by following reasons.

Firstly, ions transfer is more difficult in the solid electrolyte (NRE211 and N-117) than in the liquid electrolyte. Secondly, only preferential ions (anions or cations) are allowed to transfer through polymer electrolyte membrane (PEM), but both anions and cations can be used as carriers to transfer through polymer fiber membrane (PFM). Thirdly, in classic DBFCs, the cathode is of somehow deficiency with water as a necessary reactant for ORR. However, plenty of water is provided and mass transport resistance is lower when PFM is used.

In addition, N-117 $(183 \mu \mathrm{m})$ is much thicker than NRE-211 (25.4 $\mu \mathrm{m})$. So, ions have longer pathway in N-117 than in NRE-211. Thus, as figure $2 \mathrm{c}$ shows, the resistance of $\mathrm{N}-117$ is higher than that of NRE-211.

Careful inspection of IR-free polarisation curves in figure $2 \mathrm{~d}$, which derived from polarisation curves compensated with ohm losses, revealed that the absolute value of slope of the DBFCs-PFM is the lowest no matter in low or high over potential region (Supplementary Table 1S). The lower absolute value of slope represents the lower polarisation, and the lower reaction resistance. Therefore, it can be concluded that the DBFCs-PFM has the lowest reaction resistances, which confirms the results of figure $2 \mathrm{c}$.

Excellent performance of the DBFCs-PFM should owe to their low resistances as well as cathodic catalysts, especially $\mathrm{LaNiO}_{3}$. Because sluggish ORR of cathodic catalyst is an important factor determining the property of fuel cells ${ }^{30}$. We adopted $\mathrm{Pt} / \mathrm{C}$ as cathodic catalyst in the classic DBFCs as a comparison. Table 1 shows the peak power densities of the DBFCs. In the DBFCs with NRE-211 (the third column in table 1), the $\mathrm{LaNiO}_{3}$ cathode has the best performance at the same condition among the three catalysts. While rotating disk electrode (RDE) measurement indicates that $\mathrm{Pt} / \mathrm{C}$ has the highest transferred electron number $(n)$ than that of $\mathrm{LaNiO}_{3}$ and $\mathrm{MnO}_{2}$ (last column in table 1 ) in the ORR. It seems a contradiction that $\mathrm{Pt} / \mathrm{C}$ has the highest electron transfer number, but it has a lower power density in battery system than $\mathrm{LaNiO}_{3}$ at the same conditions. This can be explained by the crossover of fuel through the Nafion membrane. $\mathrm{Pt} / \mathrm{C}$ has catalytic nature for both borohydride oxidation reaction (BOR) and oxygen reduction reaction (ORR), borohydride ions can be decomposed by $\mathrm{Pt} / \mathrm{C}$ when they permeate to the cathode, and the reaction electrons do not pass into circuit but have been consumed in situ by $\mathrm{OH}^{-}$produced in the ORR in the cathode. Thus, the catalytic efficiency of $\mathrm{Pt} / \mathrm{C}$ becomes lower in the cathode. Because $\mathrm{LaNiO}_{3}$ and $\mathrm{MnO}_{2}$ do not react with $\mathrm{BH}_{4}{ }^{-}$, the crossover does not affect the ORR in cathodic performances. We carefully conclude that $\mathrm{Pt} / \mathrm{C}$ is not suitable as cathodic catalyst for DBFCs, unless crossover can be limited in a negligible level by more advanced ion exchange membrane.

$\mathrm{LaNiO}_{3}$ and $\mathrm{MnO}_{2}$ have similar $n$ values (2.9 and 2.8, respectively), which indicates that these catalysts have similar catalytic property for ORR, but the difference in fuel cell performances (table 1), especially in DBFCs-PFM, implies that the $n$ value cannot fully explain the electrochemical property of such metal oxides catalysts. In further research, we found that this difference is due to the resistivity of these two catalysts. The measurement of the resistivity of these two catalyst powders show that it is $1.07 \times 10^{-1}$ and $1.77 \times 10^{2}$ $\Omega \cdot \mathrm{cm}$ for $\mathrm{LaNiO}_{3}$ and $\mathrm{MnO}_{2}$, respectively (see Supplementary Information). The resistivity of catalysts greatly influences the reaction electron exchange rate between catalysts and support. Therefore, the resistivity of catalyst should be taken enough notice in non-precious metal catalyst developing.

The stability of fuel cells is another factor determining its application. Figure 3 shows the durability tests of the DBFCs-PFM for 40 hours. DBFCs with NRE-211 have also been tested in the same 
Table 1 | The peak power densities of the DBFCs and electron transfer number at $25^{\circ} \mathrm{C}$. The data obtained from Figure 2a, Supplementary Figure $3 S$ and Figure $4 S$ ( $n$ means transferred electron number per oxygen molecule in the ORR)

\begin{tabular}{lcccc} 
Catalysts in cathode & $\mathrm{PFM} / \mathrm{mW} \cdot \mathrm{cm}^{-2}$ & $\mathrm{NRE}-211 / \mathrm{mW} \cdot \mathrm{cm}^{-2}$ & $\mathrm{~N}-117 / \mathrm{mW} \cdot \mathrm{cm}^{-2}$ & $n$ \\
\hline $\mathrm{LNNiO}_{3}$ & 368 & 248 & 119 & 2.9 \\
$\mathrm{MnO}_{2}$ & 216 & 146 & 100 & 2.8 \\
$\mathrm{Pt} / \mathrm{C}$ & & 188 & 217 & 3.5 \\
\hline
\end{tabular}

conditions as a reference. Cell voltage was recorded at a constant current of $200 \mathrm{~mA} \cdot \mathrm{cm}^{2}$. The fluctuating point was due to the addition and consumption of fuel solution. The potential of DBFCs-PFM is much higher and without degradation throughout the 40-hours tests. While DBFCs with NRE-211 degrades continually in initial 10 hours, then tends to stable.

In DBFCs, there are three obstacles limiting their commercialisation: borohydride hydrolysis, liquid fuel crossover and battery $\cos ^{14}$. In our research, the last two of them have been solved in this structured fuel cell. The PFM is much cheaper and it is widely used in NiMH battery as a separator, meanwhile inexpensive catalysts can be used in both anode and cathode in the DBFC-PFM. In conventional research, crossover is a serious problem which must be resisted by increasing the thickness of the PEM or developing new PEM. However, increasing the thickness of PEM will increase ohm loss. We solve the problem by a different way that the crossover is allowed. A similar idea of allowing crossover has also been adopted in a swissroll liquid-gas mixed-reactant fuel cell ${ }^{31}$. In the situation of allowing crossover, it requires cathodic catalysts decompose $\mathrm{O}_{2}$ only and are inert to all other ions and reactants. It has been proved that the catalysts used in this work have this ability. This principle could be extended to other liquid fuel cells, such as direct methanol fuel cell (DMFC). A tentative test has been shown in Supplementary Figure 5S. A peak power density of $64 \mathrm{~mW} \cdot \mathrm{cm}^{-2}$ has been obtained at $60^{\circ} \mathrm{C}$. It is the highest value in DMFCs concerning non-Pt-based catalysts to the best of our knowledge ${ }^{32-34}$. This test provides us a clue that all liquid fuel cells can be studied in the way that crossover is no need to be considered and we just seek cathodic catalysts with selective catalysis for ORR, especially inexpensive metal oxide catalysts.

Concerning borohydride hydrolysis, there are has two ways to solve it: allowing hydrolysis and prohibiting hydrolysis. If hydrolysis is serious, we can collect hydrogen gas, which is the only by-product of the hydrolysis and feed the $\mathrm{H}_{2}$ for a $\mathrm{H}_{2} / \mathrm{O}_{2}$ PEMFC. We can develop a system in which, two fuel cells stacks work together, one is DBFE-PFM and the other is PEMFC. $\mathrm{H}_{2}$ comes from hydrolysis as a by-product in DBFC-PFM. It can omit hydrogen making

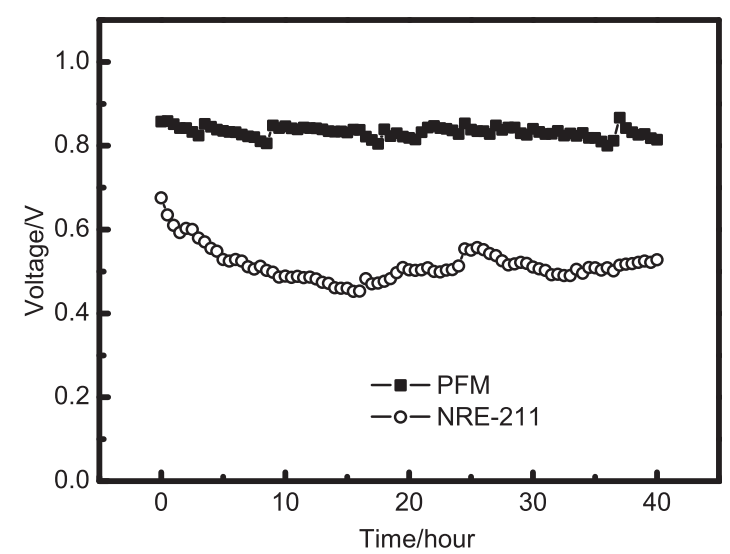

Figure 3 Comparison of fuel cell durability. Polymer fiber membrane (PFM) and NRE-211 were used in DBFCs, respectively. $\mathrm{LaNiO}_{3}$ and $\mathrm{CoO}$ were used as cathode and anode catalyst, respectively, in all cells. The current density held at $200 \mathrm{~mA} \cdot \mathrm{cm}^{2}$. and storage problem and is probably a new hydrogen energy system. For prohibiting hydrolysis, some researches indicated that Nafion film coated on anode ${ }^{35}$, and some metal catalysts could depress hydrogen evolution ${ }^{36}$. There are few researches concerning this problem and related researches need to be carried out in future.

\section{Methods}

Electrochemical characterisation. Electrochemical characterisation was performed using a rotate disk electrode (RDE, Pine Research Instrumentation) connected to a Pine AFCBP1 Bipotentiostat (Pine Research Instrumentation) assembled with a AFMSRCE rotator (Pine Research Instrumentation). A Hg/HgO (1 M KOH) electrode and Pt wire were used as reference and counter electrode, respectively. The work electrode, RDE, was modified with catalysts. The modified RDE electrode was fabricated as follows: a catalyst ink was prepared by ultrasonically mixing $3 \mathrm{mg}$ catalyst, $0.5 \mathrm{ml}$ ethanol and $15 \mu \mathrm{l} \mathrm{Nafion}(5 \mathrm{wt}$ \%) into a slurry, then spreading $10 \mu \mathrm{l}$ of the slurry onto the surface of the glass carbon electrode. The oxygen was saturated by bubbling oxygen gas into the electrolyte solution (1 M KOH) for 20 minutes before the tests.

The working electrode was scanned cathodically at a rate of $5 \mathrm{mV} \cdot \mathrm{s}^{-1}$ at RDE experiment with varying rotating speed from $400 \mathrm{rpm}$ to $2,500 \mathrm{rpm}$ at $-0.5 \mathrm{~V},-0.6 \mathrm{~V}$ and $-0.7 \mathrm{~V}$ (vs. $\mathrm{Hg} / \mathrm{HgO}$ ), respectively. The apparent number of electrons transferred (n) during the ORR calculated by the slopes of Koutecky-Levich (K-L) plots. The K-L equation is ${ }^{37}$ :

$$
\begin{gathered}
\frac{1}{J}=\frac{1}{J_{l}}+\frac{1}{J_{k}} \\
J_{k}=F A k C^{0} \\
J_{l}=0.62 n F A D_{O_{2}}^{2 / 3} v^{-1 / 6} C^{0} \omega^{1 / 2}
\end{gathered}
$$

where $J_{k}$ is kinetic current, $J_{l}$ is diffusion-limiting current, $n$ is the overall number of transferred electrons during $\mathrm{O}_{2}$ reduction, $F$ is Faraday constant $\left(96,500 \mathrm{C} \cdot \mathrm{mol}^{-1}\right), A$ is the geometric area of the electrode $\left(\mathrm{cm}^{2}\right), k$ is rate constant for oxygen reduction, $C^{D}$ is the saturated $\mathrm{O}_{2}$ concentration in the electrolyte, $D_{\mathrm{O} 2}$ is the diffusion coefficient of $\mathrm{O}_{2}$ in the electrolyte, $v$ is the kinetic viscosity of the solution, and $\omega$ is the angular frequency of the rotation in terms of $\mathrm{rad} \cdot \mathrm{s}^{-1}$.

Preparation of cathodes and anodes. The cathode for DBFCs-PFM consisted of a gas diffusion layer, a current collector and an active layer. To prepare gas diffusion layer, $60 \mathrm{wt} . \%$ acetylene black and $40 \mathrm{wt} . \%$ polytetrafluoroethylene (PTFE) (60 wt.\% PTFE solution) were mixed into slurry, then pressing the slurry into a $0.3 \mathrm{~mm}$ membrane and heating at $340^{\circ} \mathrm{C}$ for 1 hour. A non-noble metal catalyst ink was prepared by mixing 30 wt.\% catalyst, 45 wt.\% carbon nanotubes and 25 wt.\% PTFE (60 wt.\% PTFE solution). Then smeared the ink onto a current collector (nickel foam) and dried at $80^{\circ} \mathrm{C}$ for 2 hours under vacuum. The cathode electrode was finished by pressing the gas diffusion layer and the prepared current collector under $2 \mathrm{MPa}$.

The cathode for classic DBFCs was prepared by smeared the catalyst ink onto a hydrophobic treated carbon cloth and dried at $80^{\circ} \mathrm{C}$ for 2 hours under vacuum. Finally, the cathode was pressed under $2 \mathrm{MPa}$. The loading of non-noble metal cathodic catalyst was ca. $7.5 \mathrm{mg} \cdot \mathrm{cm}^{-2}$. In addition, the $\mathrm{Pt} / \mathrm{C}$ catalyst ink was prepared by mixing $50 \mathrm{wt} . \% \mathrm{Pt} / \mathrm{C}$ and $50 \mathrm{wt}$. \% Nafion (5 wt.\% Nafion solution) together. The Pt loading was $2 \mathrm{mg} \cdot \mathrm{cm}^{-2}$.

The anode used in DBFCs-PFM and classic DBFCs was prepared in the same way. The anode was prepared by mixing 97 wt.\% cobalt (II) oxide and 3 wt.\% PTFE together. Then the mixture was pasted onto the nickel foam, and dried at $80^{\circ} \mathrm{C}$ for 2 hours under vacuum. Finally, the anode electrode was pressed under a pressure of $3 \mathrm{MPa}$. The anodic catalyst loading was ca. $70 \mathrm{mg} \cdot \mathrm{cm}^{-2}$. In DMFCs, PtRu/C and Nafion solution was used as anodic catalyst and binder, respectively. The loading of $\mathrm{PtRu} / \mathrm{C}$ was ca. $6 \mathrm{mg} \cdot \mathrm{cm}^{-2}$.

Fuel cell testing. The structure of the fuel cell was shown in figure 1. The cathode contacted to oxygen flow field, while the anode connected to the fuel container. The active layer of the cathode was faced to membrane both in DBFCs-PFM and classic DBFCs. The anode, membrane and cathode were compressed together during cell assembling. The oxygen and fuel $\left(0.8 \mathrm{M} \mathrm{KBH}_{4}\right.$ and $\left.6 \mathrm{M} \mathrm{KOH}\right)$ flow rates were $5 \mathrm{sccm}$ and $20 \mathrm{ml} \mathrm{min}^{-1}$, respectively. 
The EIS of the cell, by using an electrochemical workstation (CHI650C, ChenHua, Shanghai, China), was measured at open circuit voltage (OCV) with amplitude of 10 $\mathrm{mV}$ and the frequencies ranging from $10^{5} \mathrm{~Hz}$ to $10^{-2} \mathrm{~Hz}$.

The polarisation curve of the cell was measured by increasing current and recording voltage, which controlled by a battery testing system (Neware Technology Limited, Shenzhen, China). The cell current was held at $200 \mathrm{~mA} \cdot \mathrm{cm}^{-2}$ and recorded the voltage to measure the durability of the cell. The fuel was refreshed about every 5 hours.

1. Wee, J. H. Which type of fuel cell is more competitive for portable application: direct methanol fuel cells or direct borohydride fuel cells? J. Power Sources 161, 1-10 (2006).

2. Ma, J., Choudhury, N. A. \& Sahai, Y. A comprehensive review of direct borohydride fuel cells. Renewable and Sustainable Energy Reviews 14, 183-199 (2010).

3. Jamard, R., Salomon, J., Martinent-Beaumont, A. \& Coutanceau, C. Life time test in direct borohydride fuel cell system. J. Power Sources 193, 779-787 (2009).

4. Smitha, B., Sridhar, S. \& Khan, A. A. Solid polymer electrolyte membranes for fuel cell applications-a review. J. Membr. Sci. 259, 10-26 (2005).

5. Gubler, L. \& Scherer, G. G. Trends for fuel cell membrane development. Desalination 250, 1034-1037 (2010).

6. James, B. D. \& Kalinoski, J. A. Mass Production Cost Estimation for Direct H2 PEM Fuel Cell Systems for Automotive Applications. (U.S. Department of Energy-Hydrogen Program, 2008 Annual Progress Report).

7. Jaouen, F. et al. Recent advances in non-precious metal catalysis for oxygenreduction reaction in polymer electrolyte fuel cells. Energy \& Environmental Science 4, 114-130 (2011).

8. Wu, G., More, K. L., Johnston, C. M. \& Zelenay, P. High-performance electrocatalysts for oxygen reduction derived from polyaniline, iron, and cobalt. Science 332, 443-447 (2011).

9. Lefèvre, M., Proietti, E., Jaouen, F. \& Dodelet, J.-P. Iron-based catalysts with improved oxygen reduction activity in polymer electrolyte fuel cells. Science 324, 71-74 (2009).

10. Proietti, E. et al. Iron-based cathode catalyst with enhanced power density in polymer electrolyte membrane fuel cells. Nat. Commun. 2, 416 (2011).

11. Greeley, J. et al. Alloys of platinum and early transition metals as oxygen reduction electrocatalysts. Nature Chem. 1, 552-556 (2009).

12. Lim, B. et al. Pd-Pt bimetallic nanodendrites with high activity for oxygen reduction. Science 324, 1302-1305 (2009).

13. Stamenkovic, V. R. et al. Improved oxygen reduction activity on $\mathrm{Pt} 3 \mathrm{Ni}(111)$ via increased surface site availability. Science 315, 493-497 (2007).

14. Umit B, D. Direct borohydride fuel cell: Main issues met by the membraneelectrodes-assembly and potential solutions. J. Power Sources 172, 676-687 (2007).

15. Ni, X. M. et al. A highly efficient and $\mathrm{BH}(4)(-)$ tolerant Eu2O3-catalyzed cathode for direct borohydride fuel cells. Electrochem. Commun. 12, 710-712 (2010).

16. Feng, R. X. et al. A simple and high efficient direct borohydride fuel cell with MnO2-catalyzed cathode. Electrochem. Commun. 7, 449-452 (2005).

17. Ni, X. M., Liu, Y., Wang, Y. D. \& Pan, M. Study on La2O3 as a Cathode Catalyst for Direct Borohydride Fuel Cell. Journal of the Chinese Rare Earth Society 28, 501-504 (2010).

18. Ni, X. M., Wang, Y. D. \& Pan, M. Investigation of $\mathrm{CeO} 2$ as cathode electrocatalyst for direct borohydride fuel cell. Electrochemistry 16, 43-45 (2010).

19. Ma, J. F., Wang, J. \& Liu, Y. N. Iron phthalocyanine as a cathode catalyst for a direct borohydride fuel cell. J. Power Sources 172, 220-224 (2007)

20. Ma, J. F., Liu, Y. N., Zhang, P. \& Wang, J. A simple direct borohydride fuel cell with a cobalt phthalocyanine catalyzed cathode. Electrochem. Commun. 10, 100-102 (2008).

21. Liu, Y., Ma, J. F., Lai, J. H. \& Liu, Y. N. Study of LaCoO3 as a cathode catalyst for a membraneless direct borohydride fuel cell. J. Alloys Compd. 488, 204-207 (2009).

22. Ma, J. F., Liu, Y. N., Liu, Y., Yan, Y. S. \& Zhang, P. A membraneless direct borohydride fuel cell using LaNiO3-catalysed cathode. Fuel cells 8, 394-398 (2008).
23. Li, S., Liu, Y. N., Liu, Y. \& Chen, Y. Z. Study of $\mathrm{CoO}$ as an anode catalyst for a membraneless direct borohydride fuel cell. J. Power Sources 195, 7202-7206 (2010).

24. Kim, C., Kim, K.-J. \& Ha, M. Y. Performance enhancement of a direct borohydride fuel cell in practical running conditions. J. Power Sources 180, 154-161 (2008).

25. Lee, S. M., Kim, J. H., Lee, H. H., Lee, P. S. \& Lee, J. Y. The characterization of an alkaline fuel cell that uses hydrogen storage alloys. J. Electrochem. Soc. 149 (2002).

26. Wang, L. et al. Rare earth hydrogen storage alloy used in borohydride fuel cells. Electrochem. Commun. 7, 1477-1481 (2005).

27. Qin, H., Lao, S., Liu, Z., Zhu, J. \& Li, Z. Effects of heat treatment on the structure, morphology and electrocatalytic activity of cobalt hydroxide electrocatalyst. Int. J. Hydrogen Energy 35, 1872-1878 (2010).

28. Liu, B. H., Li, Z. P., Arai, K. \& Suda, S. Performance improvement of a micro borohydride fuel cell operating at ambient conditions. Electrochim. Acta 50, 3719-3725 (2005).

29. Bidault, F., Brett, D. J. L., Middleton, P. H., Abson, N. \& Brandon, N. P. An improved cathode for alkaline fuel cells. Int. J. Hydrogen Energy 35, 1783-1788 (2010).

30. Bernardi, D. M. \& Verbrugge, M. W. A mathematical model of the solid-polymerelectrolyte fuel cell. J. Electrochem. Soc. 139, 2477-2491 (1992).

31. Aziznia, A., Oloman, C. W. \& Gyenge, E. L. A Swiss-roll liquid-gas mixedreactant fuel cell. J. Power Sources 212, 154-160 (2012).

32. Yang, C. C. Fabrication and characterization of poly(vinyl alcohol)/ montmorillonite/poly(styrene sulfonic acid) proton-conducting composite membranes for direct methanol fuel cells. Int. J. Hydrogen Energy 36, 4419-4431 (2011).

33. Yang, C. C., Chien, W. C. \& Li, Y. J. Direct methanol fuel cell based on poly(vinyl alcohol)/titanium oxide nanotubes/poly(styrene sulfonic acid) (PVA/nt-TiO2/ PSSA) composite polymer membrane. J. Power Sources 195, 3407-3415 (2010).

34. Yang, C. C., Chiu, S. J., Chien, W. C. \& Chiu, S. S. Quaternized poly(vinyl alcohol)/ alumina composite polymer membranes for alkaline direct methanol fuel cells. J. Power Sources 195, 2212-2219 (2010).

35. Li, Z. P., Liu, B. H., Zhu, J. K. \& Suda, S. Depression of hydrogen evolution during operation of a direct borohydride fuel cell. J. Power Sources 163, 555-559 (2006).

36. Liu, B. H., Li, Z. P. \& Suda, S. Electrocatalysts for the anodic oxidation of borohydrides. Electrochim. Acta 49, 3097-3105 (2004).

37. Bard, A. J. \& Faulkner, L. R. Electrochemical Methods: Fundamentals and Applications. 2 edn, (Wiley, 2000).

\section{Acknowledgements}

The authors are grateful for the financial support of NSFC (Grant No. 50871082), Key State Lab. Foundation of China. And the authors are also grateful for professors Binjun Ding and associate professor Chunsheng Yang and graduate student Lina Zhuang in School of Science, Xi'an Jiaotong University for helpful discussion, and providing assistance in instrument of rotate disk electrode (RDE, Pine Research Instrumentation).

\section{Author contributions}

$\mathrm{XY}$ proposed the concept. YL directed the research. XY, YL, SL and XW designed the experiments. XY, SL, XW, LW and YC carried out the experiments. XY and YL wrote the main manuscript text and prepared figures. All authors reviewed the manuscript.

\section{Additional information}

Supplementary information accompanies this paper at http://www.nature.com/ scientificreports

Competing financial interests: The authors declare no competing financial interests. License: This work is licensed under a Creative Commons Attribution-NonCommercial-ShareAlike 3.0 Unported License. To view a copy of this license, visit http://creativecommons.org/licenses/by-nc-sa/3.0/

How to cite this article: Yang, X. et al. A direct borohydride fuel cell with a polymer fiber membrane and non-noble metal catalysts. Sci. Rep. 2, 567; DOI:10.1038/srep00567 (2012). 